\title{
Flight Activities and Pollen Load of Lepidotrigona terminata Smith (Apidae: Meliponinae)
}

\author{
Anggun Wicaksono ${ }^{1,2}$, Tri Atmowidi ${ }^{1 *}$, Windra Priawandiputra ${ }^{1}$ \\ ${ }^{1}$ Animal Biosciences Study Program, Department of Biology, Faculty of Mathematics and Natural Sciences, IPB University, Bogor, \\ Indonesia \\ ${ }^{2}$ Biology Education Study Program, Faculty of Tarbiyah and Teacher Training, Raden Fatah State Islamic University, Palembang, \\ Indonesia
}

ARTICLE INFO

Article history:

Received April 25, 2017

Received in revised form November 20, 2019

Accepted November 30, 2019

\section{KEYWORDS:}

Stingless bee, acetolysis,

environmental conditions,

pollen grains,

selection index

\begin{abstract}
Worker bees actively forage to supply colony necessity i.e., pollens, nectar, and resin. Flight activities of the worker bees are influenced by food availability and environmental conditions. This study aimed to measure flight activities of Lepidotrigona terminata in terms of leaving and returning to the nest (including carrying of pollen and pollen type) and their relation to environmental conditions. The observation of flight activities of $L$. terminata were conducted from August to December 2016, at 07.00-17.00 for 1 minute with 1 hour interval. Pollen load and pollen types were analyzed by the acetolysis method. Flight activities of leaving and returning to the nest were lower at $07.00-08.00$ ( 1 individual $/ \mathrm{min})$ and at 16.0017.00 ( 2 individuals/min). However, the peak activities occurred at 10.00 until 13.00 (8 and 6 individuals/min for leaving and returning to the nest, respectively). Temperature and light intensity were positively correlated with flight activities of bees that carried nectar and resin, as well as leaving the nest without garbage. The returned workers averagely carried 32,696 pollen grains from four pollen types. Based on selection index values, this stingless bee species mostly preferred Araceae $\left(w_{i}=1.522\right)$ plant family for pollen resources to others, Anacardiaceae, Aceraceae, and Acanthaceae $\left(x^{2}=39.32, p<0.01\right)$.
\end{abstract}

\section{Introduction}

Stingless bees (Apidae: Meliponinae) are eusocial insects that live in colonies (Michener 1974; Inoue et al. 1985). Stingless bees have caste division, consist of queens, males, and workers (Michener 1974). Queen bee has an important role as new individual producer, while drones mate the queen bee(Sakagami and Yamane 1987; Boongird and Michener 2010). The worker bees are the females that responsible to foraging, cleaning, guarding, and making a nest (Inoue et al. 1985; Sakagami and Yamane 1987; De Bruijn and Sommeijer 1997; Nugroho and Soesilohadi 2015).

Foraging of worker bees is an essential activity for collecting resources (pollen, nectar, resins, and wax) (De Bruijn and Sommeijer 1997; Boongird and Michener 2010). Nectar is a flower essence which from liquid containing sugar as an energy source

* Corresponding Author

E-mail Address: atmowidi@apps.ipb.ac.id of bees (Inoue et al. 1985; De Bruijn and Sommeijer 1997; Ramalho et al. 1998; Boongird and Michener 2010). Stingless bee need pollen and nectar as nutrition for individual and their colony (Ramalho et al. 1998; Atmowidi et al. 2007, 2008). However, Eltz and Gorke (2002) reported that, Trigona collina is not only used pollen and nectar as food sources but also fungal spores as alternative. Wax is a compound produced by plants used as substance for construction of bee's nest (Wille 1983). Flight activity of worker bees also collect the resins. Resin is a main substance for nest construction used as defense system to against predators (Sakagami et al. 1989; De Bruijn and Sommeijer 1997; Lehmberg et al. 2008; Duangphakdee et al. 2009).

Flight activities of stingless bees are influenced by several environmental conditions, i.e., temperature, light intensity, humidity, and wind velocity (Heard and Hendrikz 1993; Vicens and Bosch 2000; Nugroho and Soesilohadi 2015). Other factors such as food sources also could influence flight activities (Inoue 
et al. 1985; Atmowidi et al. 2008; Amzi et al. 2015; Nugroho and Soesilohadi 2015). Consequently, study of flight activities (leaving and returning to the nest) and pollen load is an essential knowledge for pollination of stingless bee species. One of stingless bee species in Indonesia that has potential for pollination is Lepidotrigona terminata (Klein et al. 2003a, 2003b; Asmini 2016).

Lepidotrogona terminata is widely distributed stingless bee in Indonesia, including Java, Sumatera, Borneo, and Sulawesi (Klein et al. 2003a, 2003b; Smith 2012; Syafrizal et al. 2014). The species was characterized by yellow or white ring on the thoracic, in outside of mesocutum and mesoscutellum (Schwarz 1939; Smith 2012). Activities of L. terminata are effective for pollination, i.e., able to collect 33 pollen types in Thailand (Jongjitvimol and Poolprasert 2014), increases fruit formation in coffea (Klein et al. 2003a, 2003b), and enhance number of seeds in mustard (Asmini 2016). Moreover, they could enhance pollination because its small body size which compatible with small flowers (Amzi et al. 2015). Unfortunately, study of flight activities and pollen load of $L$. terminata rarely conducted. Therefore, this study aimed to i) measure the flight activities of $L$. terminata, ii) counted and identified carrying pollen load, and iii) examined the correlation between flight activities and environmental conditions.

\section{Materials and Methods}

\subsection{Study Sites}

Observation of flight activities for one colony $L$. terminata was conducted from August to December 2016 in Field Laboratory of Animal Biosystematics and Ecology, Bogor. In around of the bee colony were found wild plants such as trees, weeds, and flowering plants. Pollen type and pollen load were identified and measured at laboratory of Animal Biosystematics and Ecology, Department of Biology, Faculty of Mathematics and Natural Sciences, IPB University, Bogor, West Java.

\subsection{Procedures}

\subsubsection{Observation of Flight Activities}

One colony of L. terminata was used to observe the flight activities. Size of the bee colonies of $L$. terminata used was relatively large (2,000-2,500 individuals). Observation of flight activities (leaving and returning to the nest) were conducted one minute in each one hour interval starting from 07.00 to 17.00 for 15 days in a sunny day. Those activities were recorded by using handycam Panasonic (60x zoom). The returning number of individu with carrying pollen and resin, and the leaving number of individual with and without carrying garbage were counted (Figure 1 ). Individuals of $L$. terminata that did not carry pollen or resin were assumed to carry nectar. Measurement of environmental factors (temperature, humidity, and light intensity) were conducted before observation of flight activities.

\subsubsection{Pollen Identification}

The pollen identification was used by acetolysis method (Erdtman 1960). Fifteen individuals of $L$. terminata that returning to the nest with pollen load were collected using insect net. Pollens on the legs were taken by using sterile tweezers, and then, those pollens were put in a $1.5 \mathrm{ml}$ tube with $1 \mathrm{ml}$ acetolysis solution. Furthermore, there were heated at $80^{\circ} \mathrm{C}$ in water bath for 5 minutes and were centrifuged at 3,500 rpm for 10 minutes. Acetolysis solution was discarded from tube while pollen that kept in the tube was rinsed with distilled water and were continuously centrifugated at

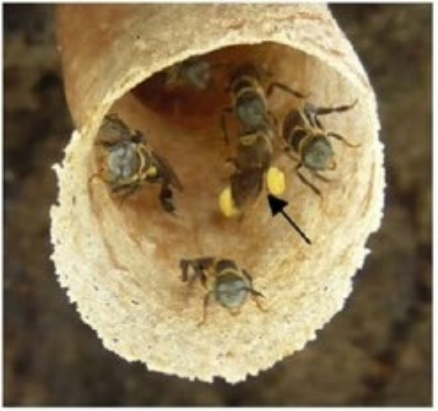

a

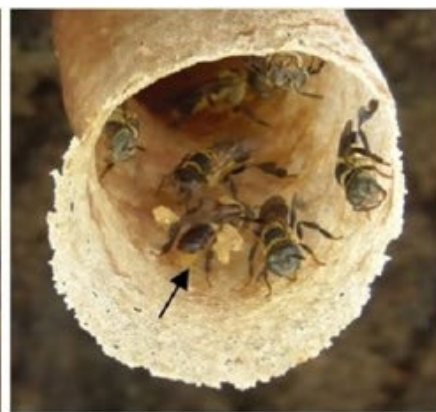

b

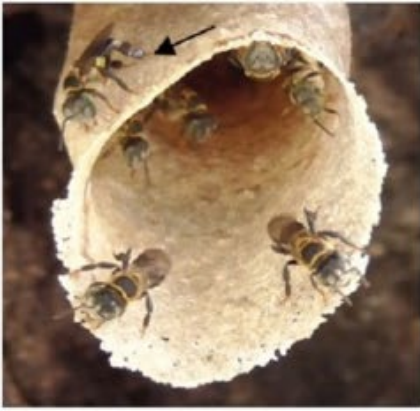

C

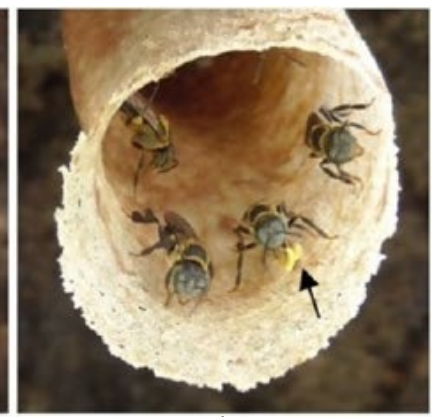

d

Figure 1. Activity of leaving and returning to the nest of L. terminata, (a) returning to the nest carrying pollen, (b) returning to the nest carrying resins, (c) returning to the nest carrying nectar, and (d) leaving the nest with and without carrying garbage. The arrows represent activity of each bee individuals 
3,500 rpm for 10 minutes. Rinsing was repeated until the rinse solution looked clear. Pollens were dried in oven at $60^{\circ} \mathrm{C}$ for 24 hours. After that, $0.5 \mathrm{ml}$ of glycerin $30 \%$ was added and tube was stirred until there was no clot. The pollens were prepared on the slides using micropipette and was covered. Then, the pollens were observed under a Nikkon C-LEDS 102 microscope (30x magnification) and were captured using optilab camera. All pollens were identified based on morphological characters i.e., the numbers of apertures, pollen shape (polar and equatorial view), ornaments of exine, and pollen size (Huang 1972; APSA 2007).

\subsubsection{Pollen Load Measurement}

Pollens from 15 worker bees were collected. Each individual of worker bees with pollen on hind legs was put into the tube contained $0.5 \mathrm{ml}$ of alcohol:glycerol $(4: 1)$. Then rotated for 24 hours and individual was removed from tube. The tube was centrifuged at 2,000 rpm for 10 minutes. The supernatant was discarded and remained as much as $0.1 \mathrm{ml}$ with sediment. Remained solution was homogenized and the solution was dropped into Neubauer-type hemocytometer. The numbers of pollens were counted by using compound microscope (400 x 10 magnification). Image Raster 3 software also was used to observe and measure the pollens.

\subsection{Data Analysis}

Correlation between flight activities of $L$. terminata and environmental factors (temperature, humidity, and light intensity) were analyzed by Pearson correlation using Minitab 16.0 software. The selection resource of individual L. terminata was analyzed using modification formula of 1) selection index $\left.\left(w_{i}\right), 2\right)$ G-test (Chisquared $)\left(\mathrm{x}^{2}\right)$, and 3$)$ comparison of two selection index $\left(\mathrm{x}^{2}\right)$ (Manly et al. 1993; Krebs 1998). Those modification formulas were showed as below:

$$
\begin{aligned}
& \text { 1. } w_{i}=\frac{o_{i}}{p_{i}} \\
& \text { 2. } x^{2}=2 \sum_{i=0}^{n}\left[u_{i} \ln \left(\frac{u_{i}}{U_{p_{i}}}\right)\right] \\
& \text { 3. } x^{2}=\frac{\left(\dot{\mathrm{w}}_{i}-\dot{\mathrm{w}}_{j}\right) 2}{\text { variance }\left(\dot{\mathrm{w}}_{i}-\dot{\mathrm{w}}_{j}\right)} \\
& \text { variance }\left(\dot{\mathrm{w}}_{i}-\dot{\mathrm{w}}_{j}\right)=\frac{o_{i}\left(1-o_{i}\right)}{U_{p_{i}}{ }^{2}}-\frac{2 o_{i} o_{j}}{U_{p_{i}} p_{j}}+\frac{o_{j}\left(1-o_{j}\right)}{U_{p_{j}}{ }^{2}}
\end{aligned}
$$

Where, $w_{i}$ and $w_{j}$ representing the forage ratio of number individuals for resource $i$ or $j . o_{i}$ and $o_{j}$ representing the proportion of number pollen of resource $i$ or $j . p_{i}$ and $p_{j}$ representing the proportion of number individuals carrying pollen types $i$ or $j . u_{i}$ and $U$ representing the number and total number of individual observations, respectively.

\section{Results}

\subsection{Flight Activities of $L$. terminata}

The leaving and returning to the nest of $L$. terminata have similar pattern (Figure 2). The activities started in early morning $07.00-08.00$ with low number of individuals ( 1 individual $/ \mathrm{min}$ ). The number of individuals gradually increased until 09.00-10.00 and there were relatively constant from 09.00-13.00. However, the peak flight activities occurred at 10.00 to 13.00 ( 8 and 6 individuals/min for leaving and returning to the nest). The flight activities were slightly decreased from 14.00-15.00 to $16.00-17.00$ ( 2 individuals/min).

Activity of leaving the nest without carrying garbage was constantly higher than with carrying garbage (Figure 3a). The peak activities of leaving the nest carrying garbage occurred at 09.00-10.00 (2 individuals/min). Leaving activities without carrying garbage were relatively constant from 08.00-14.00. However, the peak activities occurred at $12.00-13.00$ ( 8 individuals/min) and then slightly decreased. Meanwhile, the activities of returning to the nest showed various patterns (Figure $3 \mathrm{~b})$. Peak of activities in returning to the nest $L$. terminata carrying pollens occurred at 09.00-10.00 ( 2 individuals/min). Contrary, activities of carrying pollen decreased, whereas activities of carrying resins and nectar increased at 12.00-13.00. Peak activities carrying resins ( 1 individual/min) and nectar (5 individuals/min) were relatively constant from 09.00-15.00.

Environmental factors such as temperatures, humidity, and light intensity around the nest of $L$. terminata varied during sampling period (Table 1 ). The average of minimum and maximum temperatures occurred at $07.00-08.00\left(26.2^{\circ} \mathrm{C}\right)$ and at $12.00-13.00\left(37^{\circ} \mathrm{C}\right)$, respectively. Contrary, average of minimum and maximum humidities presented at $12.00-13.00(39.3 \%)$ and at $08.00-09.00$ (81.1\%), respectively. The average of minimum light 


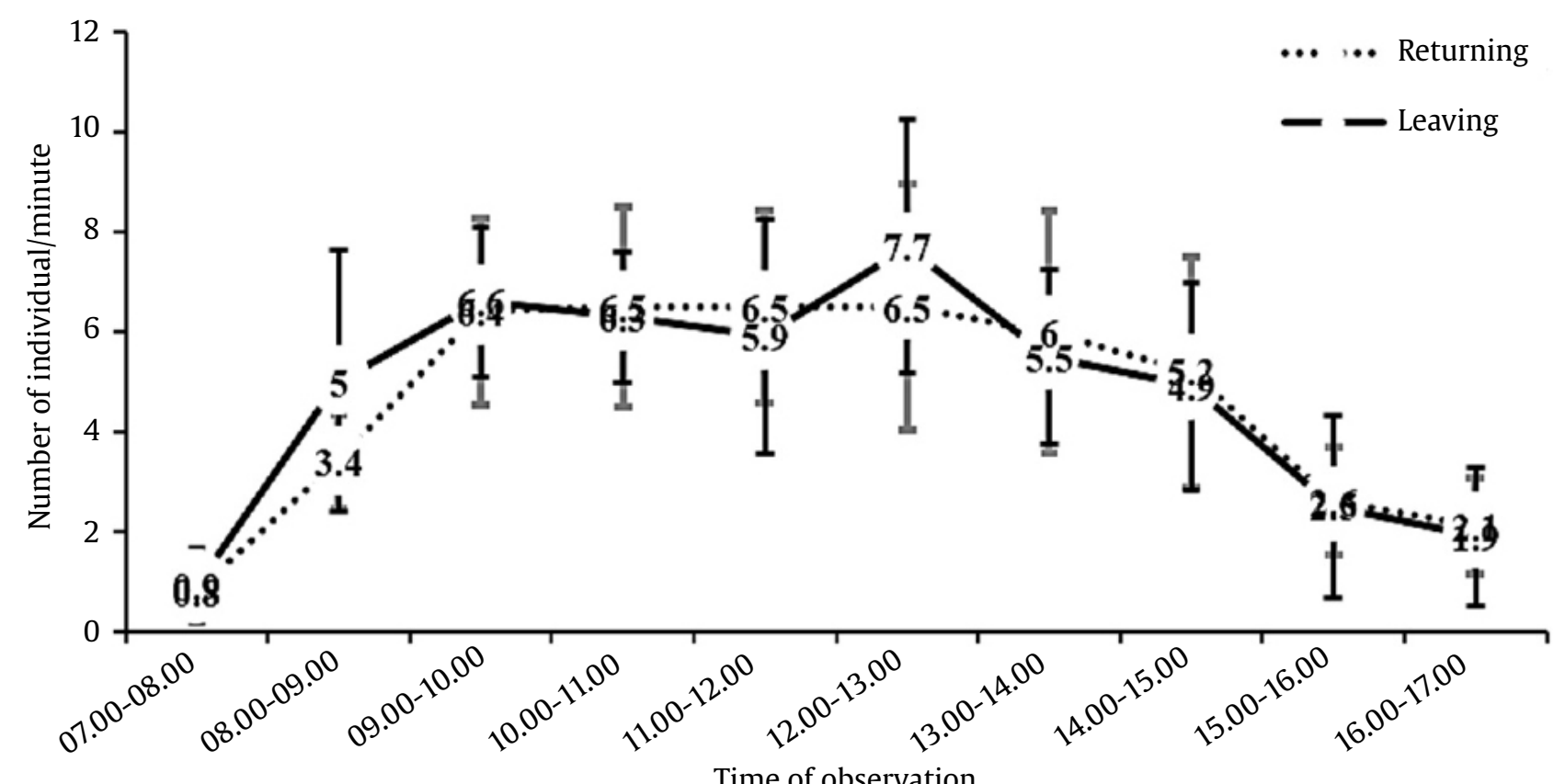

Figure 2. Activity of leaving and returning to the nest of $L$. terminata

intensity at $16.00-17.00$ was 4,200 lux, while the average of maximum light intensity at 12.00-13.00 was 25,500 lux.

Correlations between all flight activities including leaving and returning to the nest were presented in Table 2. Based on Pearson correlation test, temperature and light intensity were positively correlated with all flight activities while negatively correlated with humidity. The temperature have positive correlation with returning to the nest carrying nectar $(\mathrm{r}=0.873, \mathrm{p}=0.001)$, carrying resins $(r=0.976, p=0.000)$, and leaving the nest without carrying garbage $(\mathrm{r}=0.741, \mathrm{p}=0.014)$. The light intensity have positive correlation with all flight activities, i.e., returning to the nest carrying nectar $(r=0.780, p=0.008)$, carrying pollen $(r=0.578$, $\mathrm{p}=0.080)$, carrying resins $(\mathrm{r}=0.670, \mathrm{p}=0.034)$, leaving without carrying garbage $(\mathrm{r}=0.884, \mathrm{p}=0.001)$, and with carrying garbage $(\mathrm{r}=0.548, \mathrm{p}=0.101)$. Contrary, humidity have negative correlation with all flight activities, i.e., returning to the nest carrying nectar $(\mathrm{r}=-0.879, \mathrm{p}=0.001)$, carrying pollen $(\mathrm{r}=-0.047$, $\mathrm{p}=0.898)$, carrying resins $(\mathrm{r}=-0.969, \mathrm{p}=0.000)$, leaving without carrying garbage $(\mathrm{r}=-0.720, \mathrm{p}=0.019)$, and with carrying garbage $(\mathrm{r}=-0.195, \mathrm{p}=0.590)$.

\subsection{Pollen Types and Pollen Load}

Based on morphological characters of pollen carried by $L$. terminata, pollen was classified into four types of plant family. Those pollens belong to Anacardiaceae, Araceae, Aceraceae, and Acanthaceae (Figure 4). Pollen type of Anacardiaceae and Araceae have a small size with approximately $10 \mu \mathrm{m}$ in diameter. While, pollen type of Aceraceae and Acanthaceae have a large size with approximately $50 \mu \mathrm{m}$ in diameter.

The average of pollen load of $L$. terminata was 32,696 pollen grains (Table 3 ). The highest number of pollen grains of Araceae mostly attached in hindlegs of L. terminata (452,405 pollen grains). Meanwhile, the lowest number belong to Acanthaceae $(1,445$ pollen grains).

The highest of selection index was Araceae $\left(w_{i}=1.522\right)$, followed by Anacardiaceae $\left(w_{i}=0.242\right)$, Aceraceae $\left(w_{i}=0.032\right)$, and Acanthaceae $\left(w_{i}=0.003\right)$ (Table 3).There were significant different of selection index among pollen types $\left(x^{2}=39.32, p<0.01\right)$. Based on two selection indices test, pollen of Araceae was significantly differences with Anacardiaceae, Aceraceae, and Acanthaceae $\left(\mathrm{x}^{2}>83, \mathrm{p}<0.01\right)$. 


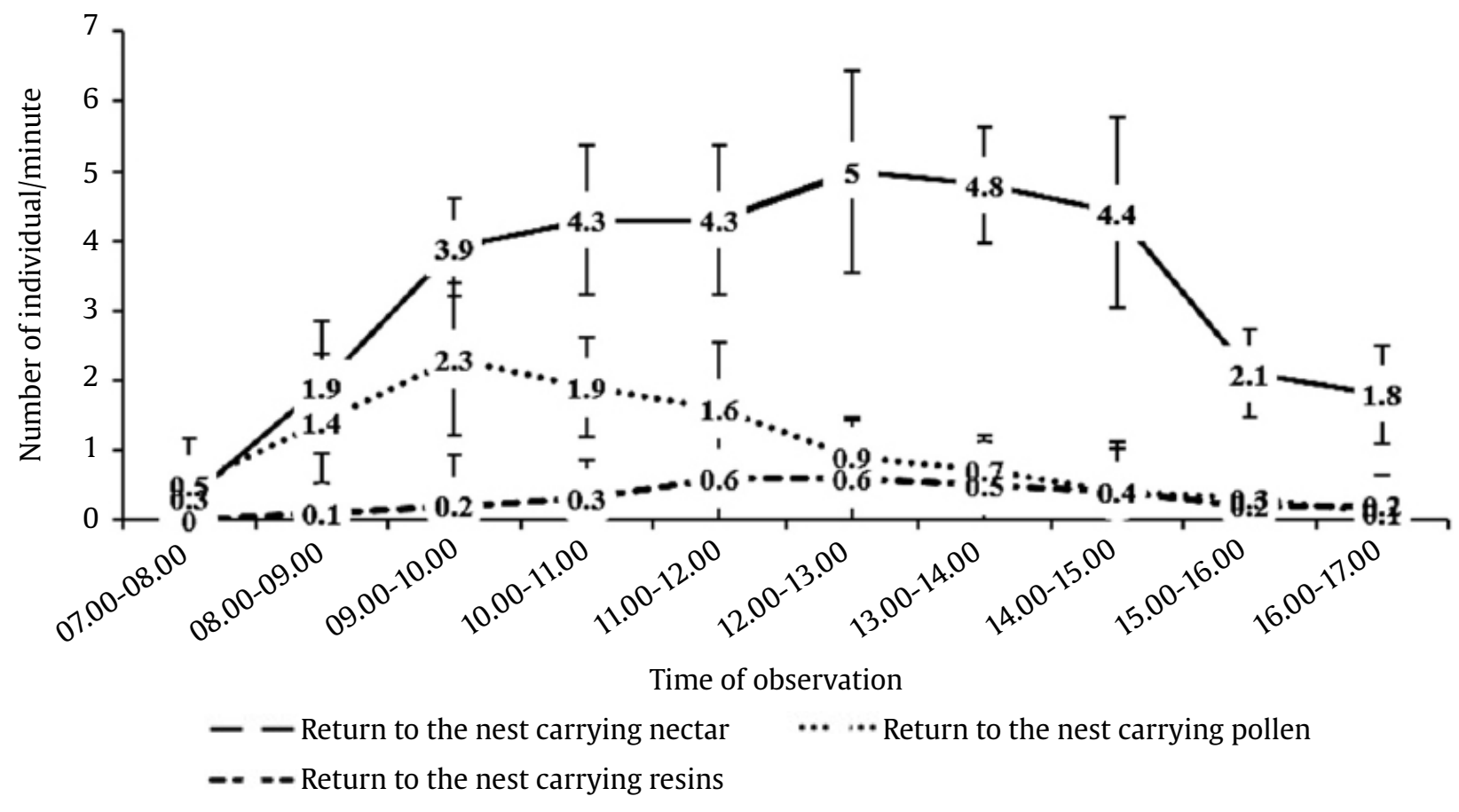

a

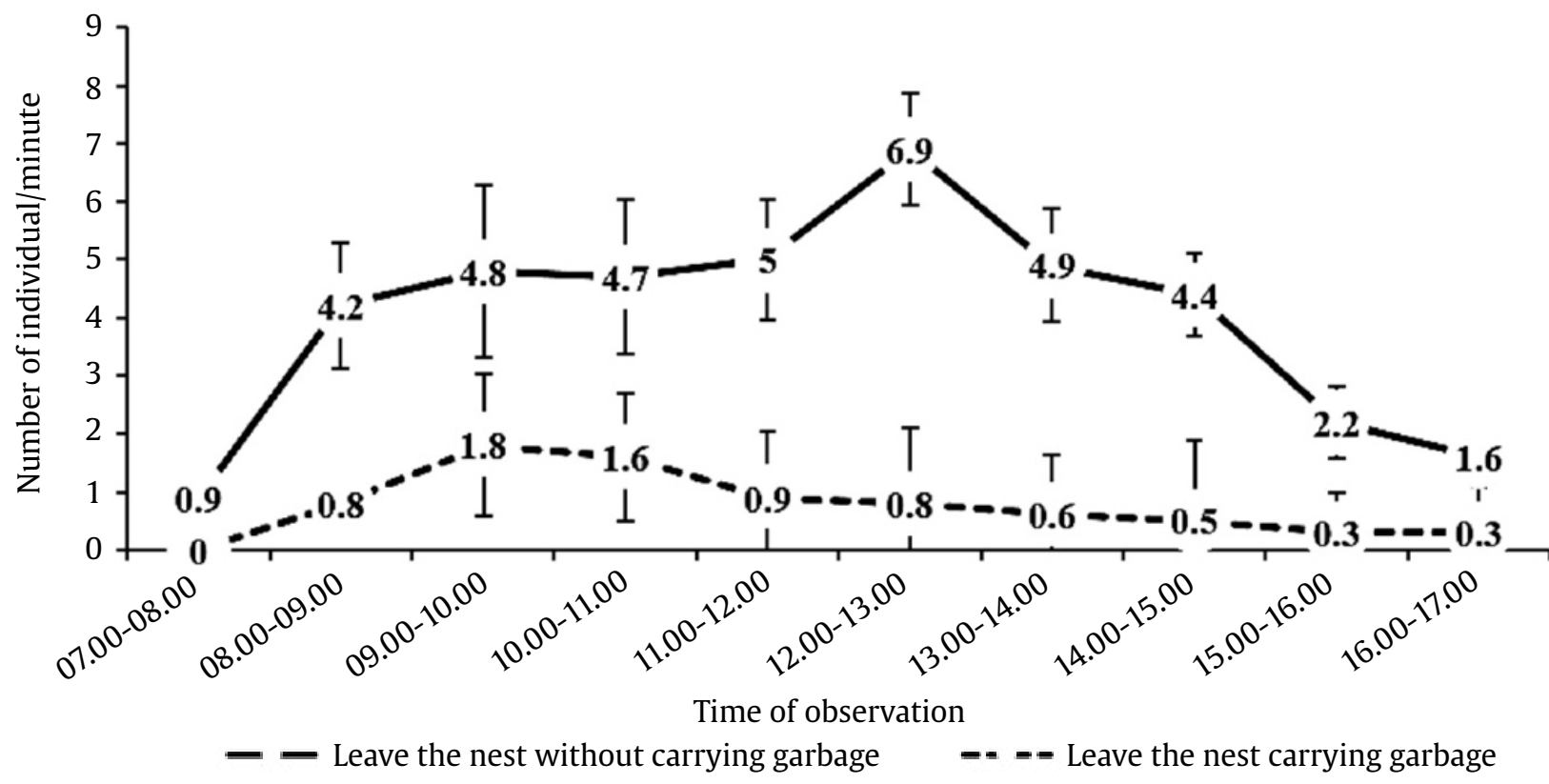

$\mathrm{b}$

Figure 3. Activity of leaving and returning to the nest L. terminata, (a) leaving with and without carrying garbage and (b) returning carrying nectar, pollens, and resins

Meanwhile, there were not significantly differences between pollen of Anacardiaceae with Aceraceae and Acanthaceae $\left(\mathrm{x}^{2}<1.015, \mathrm{p}>0.05\right)$. Moreover, no significant different was also found between Aceraceae and Acanthaceae $\left(x^{2}=1.027, p>0.05\right)$. 
Table 1. Environmental factors (temperature, humidity, and light intensity) measured around the nest $L$. terminata during observations

\begin{tabular}{lcrrrrrrrrr}
\hline & \multicolumn{10}{c}{ Time of observation } \\
\cline { 2 - 11 } Parameters & $07.00-$ & $08.00-$ & $09.00-$ & $10.00-$ & $11.00-$ & $12.00-$ & $13.00-$ & $14.00-$ & $15.00-$ & $16.00-$ \\
& 08.00 & 09.00 & 10.00 & 11.00 & 12.00 & 13.00 & 14.00 & 15.00 & 16.00 & 17.00 \\
\hline Temperature $\left({ }^{\circ} \mathrm{C}\right)$ & & & & & & & & & & \\
$\quad$ Average & 26.2 & 27.2 & 29.8 & 32.5 & 36.7 & 37.0 & 36.0 & 33.6 & 31.6 & 28.6 \\
$\quad$ Minimum & 24.5 & 25.3 & 23.9 & 29.4 & 31.0 & 31.8 & 26.0 & 25.8 & 25.4 & 24.6 \\
$\quad$ Maximum & 27.3 & 29.2 & 33.3 & 37.3 & 42.6 & 43.1 & 43.7 & 40.8 & 39.3 & 32.6 \\
\hline Humidity (\%) & & & & & & & & & & \\
$\quad$ Average & 81.1 & 78.2 & 64.9 & 56.8 & 42.8 & 39.3 & 42.9 & 52.2 & 58.8 & 68.2 \\
$\quad$ Minimum & 77.0 & 64.0 & 43.0 & 33.0 & 25.0 & 24.0 & 22.0 & 26.0 & 31.0 & 45.0 \\
$\quad$ Maximum & 86.0 & 89.0 & 71.0 & 73.0 & 72.0 & 57.0 & 79.0 & 87.0 & 81.0 & 88.0 \\
\hline Light intensity (x 100 lux) & & & & & & & & & & \\
$\quad$ Average & 12.7 & 15.7 & 18.9 & 20.9 & 21.7 & 25.5 & 21.3 & 17.7 & 5.9 & 4.2 \\
$\quad$ Minimum & 2.0 & 8.0 & 12.0 & 6.0 & 11,0 & 10.0 & 3.0 & 1.0 & 1.0 & 1.0 \\
$\quad$ Maximum & 19.0 & 34.0 & 31.0 & 55.0 & 43.0 & 51.0 & 90.0 & 54.0 & 13.0 & 10.0 \\
\hline
\end{tabular}

Table 2. Pearson correlation ( $\mathrm{r}$ ) and probability (p) between environmental factors and flight activities

\begin{tabular}{lccccccc}
\hline \multirow{2}{*}{ Parameters } & \multicolumn{7}{c}{ Flight activities } \\
\cline { 2 - 8 } & Returning & Leaving & $\begin{array}{l}\text { Return } \\
\text { carrying } \\
\text { nectar }\end{array}$ & $\begin{array}{l}\text { Return } \\
\text { carrying } \\
\text { pollens }\end{array}$ & $\begin{array}{l}\text { Return } \\
\text { carrying } \\
\text { resins }\end{array}$ & $\begin{array}{l}\text { Leave } \\
\text { without } \\
\text { carrying } \\
\text { garbage }\end{array}$ & $\begin{array}{l}\text { Leave } \\
\text { carrying } \\
\text { garbage }\end{array}$ \\
\hline Temperature & $\mathrm{r}=0.768$ & $\mathrm{r}=0.660$ & $\mathrm{r}=0.873$ & $\mathrm{r}=0.081$ & $\mathrm{r}=0.976$ & $\mathrm{r}=0.741$ & $\mathrm{r}=0.195$ \\
& $\mathrm{p}=0.009$ & $\mathrm{p}=0.038$ & $\mathrm{p}=0.001$ & $\mathrm{p}=0.824$ & $\mathrm{p}=0.000$ & $\mathrm{p}=0.014$ & $\mathrm{p}=0.590$ \\
Humidity & $\mathrm{r}=-0.760$ & $\mathrm{r}=-0.643$ & $\mathrm{r}=-0.879$ & $\mathrm{r}=-0.047$ & $\mathrm{r}=-0.969$ & $\mathrm{r}=-0.720$ & $\mathrm{r}=-0.195$ \\
& $\mathrm{p}=0.011$ & $\mathrm{p}=0.045$ & $\mathrm{p}=0.001$ & $\mathrm{p}=0.898$ & $\mathrm{p}=0.000$ & $\mathrm{p}=0.019$ & $\mathrm{p}=0.590$ \\
Light intensity & $\mathrm{r}=0.841$ & $\mathrm{r}=0.868$ & $\mathrm{r}=0.780$ & $\mathrm{r}=0.578$ & $\mathrm{r}=0.670$ & $\mathrm{r}=0.884$ & $\mathrm{r}=0.548$ \\
& $\mathrm{p}=0.002$ & $\mathrm{p}=0.001$ & $\mathrm{p}=0.008$ & $\mathrm{p}=0.080$ & $\mathrm{p}=0.034$ & $\mathrm{p}=0.001$ & $\mathrm{p}=0.101$ \\
\hline
\end{tabular}

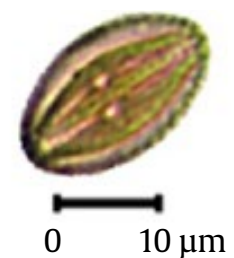

$1^{\text {a }}$

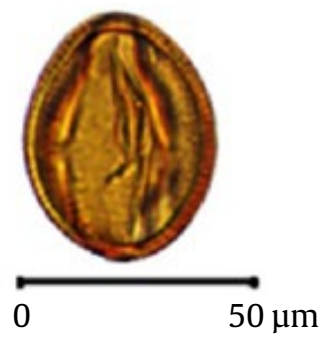

$3^{a}$

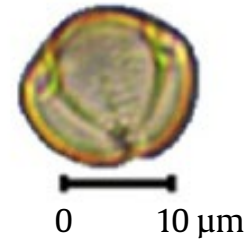

$1^{\mathrm{b}}$

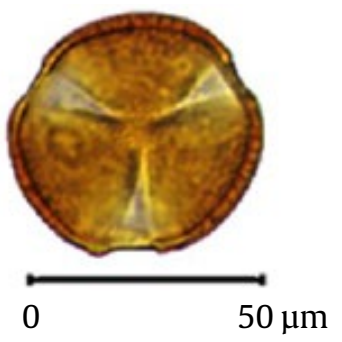

$3^{\mathrm{b}}$

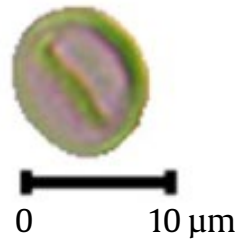

$2^{\mathrm{a}}$

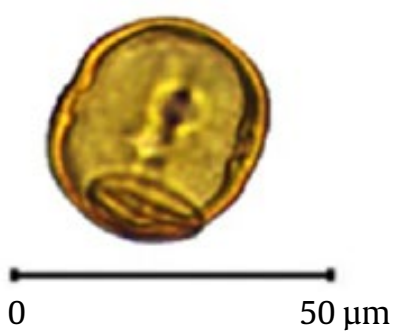

$4^{a}$

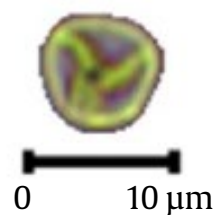

$2^{\mathrm{b}}$

Figure 4. Images of various pollen types attached on L. terminata, (a) polar and (b) equatorial view, 1: Anacardiaceae, 2: Araceae, 3: Aceraceae, and 4: Acanthaceae 
Table 3. Number of pollen from each individual of $L$. terminata and selection index $\left(\boldsymbol{w}_{i}\right)$ of each plant family

\begin{tabular}{|c|c|c|c|c|c|}
\hline \multirow{2}{*}{ Individual } & \multicolumn{4}{|c|}{ Family (plants) } & \multirow[b]{2}{*}{ Total } \\
\hline & Araceae & Anacardiaceae & Aceraceae & Acanthaceae & \\
\hline 1 & 99,275 & 0 & 0 & 0 & 99,275 \\
\hline 2 & 0 & 8,150 & 0 & 0 & 8,150 \\
\hline 3 & 30,915 & 0 & 0 & 0 & 30,915 \\
\hline 4 & 0 & 0 & 4,600 & 0 & 4,600 \\
\hline 5 & 0 & 5,525 & 0 & 0 & 5,525 \\
\hline 6 & 0 & 0 & 11,055 & 0 & 11,055 \\
\hline 7 & 87,070 & 0 & 0 & 0 & 87,070 \\
\hline 8 & 5,235 & 0 & 0 & 0 & 5,235 \\
\hline 9 & 0 & 7,260 & 0 & 0 & 7,260 \\
\hline 10 & 85,885 & 0 & 0 & 0 & 85,885 \\
\hline 11 & 133,385 & 0 & 0 & 0 & 133,385 \\
\hline 12 & 5,920 & 0 & 0 & 0 & 5,920 \\
\hline 13 & 0 & 0 & 0 & 1,445 & 1,445 \\
\hline 14 & 3,260 & 0 & 0 & 0 & 3,260 \\
\hline 15 & 1,460 & 0 & 0 & 0 & 1,460 \\
\hline Number of pollen & 452,405 & 20,935 & 15,655 & 1,445 & 490,440 \\
\hline Average of pollen & $30,160.3$ & $1,395.6$ & $1,043.6$ & 96.3 & 32,696 \\
\hline Selection index $\left(w_{i}\right)$ & 1.522 & 0.242 & 0.165 & 0.069 & \\
\hline
\end{tabular}

\section{Discussion}

\subsection{Flight Activities}

Based on Pearson correlation test, environmental factors correlated with flight activities (Table 2). In lower termperature, bees increase thoracic temperature with wings flapping (Stone and Willmer 1989). Bees adjust to the ambient temperature with their thermoregulation system (Eltz et al. 2001; Syafrizal et al. 2014). Bees also use a light as direction to forage and increase body temperature. Limitation of light may to restrict flight activity of bees, like Megalopta genalis and Trigona carbonaria (Heard and Hendrikz 1993; Kelber et al. 2006). Air humidity also affected the activity of $L$. terminata where increasing humidity could decreaseflight activity. Flightactivities of leaving and returning to the nest increased in the morning to mid-day and decreased in the afternoon (Figure 2). When temperature was high in the midday $\left(26.2-37^{\circ} \mathrm{C}\right)$, stingless bees are actively foraging (Stone and Willmer 1989; Nugroho and Soesilohadi 2015). Meanwhile, there was no activity of leaving and returning to the nest when raining.

Flight activities of returning to the nest carrying nectar occurred during the mid-day (10.00-14.00) (Figure $3 \mathrm{~b}$ ). Those activities increased in the average temperature $37^{\circ} \mathrm{C}$ and humidity $39.3 \%$ (Table 1 ). Activity of stingless bee carrying nectar increased in the mid-day (12.00-13.00) and decreased in the afternoon. Moreover, high necessity of nectar in the afternoon have positive correlation with ambient temperature. The nectar concentrated by water evaporation in the mid-day until afternoon is a suitable concentration for bees (Inoue et al. 1985; De Bruijn and Sommeijer 1997). Water on bee's body is used to decrease temperature in the nest (De Bruijn and Sommeijer 1997). Availability of plant and nectar quality become prominent factors for honey production (Bhuiyan et al. 2002).

Peak of flight activity returning to the nest carrying pollen occurred in the morning (09.00-10.00) (Figure $3 \mathrm{~b}$ ). Those, activity increased in average temperature $29.8^{\circ} \mathrm{C}$ and humidity $64.9 \%$ (Table 1 ). In the morning, there are much pollen in the flower (Sommeijer $e t a l$. 1983; Inoue et al. 1985; Atmowidi et al. 2008), whereas in the afternoon there are less pollens, however bees still need to visit some flowers to collect pollen (Atmowidi et al. 2007). Amzi et al. (2015) stated that time of flower anthesis occurs mostly in the morning and the flowers are close mostly in the afternoon. The pollen-taking process such as flight range, pollen collection and pollen handling time associated to flowers blooms that mostly in the morning. Flight range of bees are farther and need a lot of time for pollen collection (Inoue et al. 1985; Biesmeijer and Toth 1998). Time for pollen collection, pollen load and pollen quality also affect the flight activities of bees and productivity of the colony (De Bruijn and Sommeijer 1997; Biesmeijer and Toth 1998; Ramalho et al. 1998; Nagamitsu and Inoue 2002). The large 
number of $L$. terminata individual carrying pollen in the morning indicated effective time for pollination where pollen foraging in mid-day until afternoon slightly decreased (Figure 3b). Other factors also affect foraging of bees such as landscapes structures where forest habitat is important element of landscape for bees because it provides diversity of plant resources (nectar, pollen, and resin) (Priawandiputra et al. 2015).

Peak of flight activity returning to the nest carrying resins occurred in the mid-day (11.00-13.00). Based on observations, activities of $L$. terminata carrying resin was performed in high ambient temperature $37^{\circ} \mathrm{C}$ (Figure 3). Sticky character of resin on the hind tibias of Melipona stingless bees disturbs flight activities (De Bruijn and Sommeijer 1997). Results showed that activity carrying resin from morning to afternoon was the lowest compared to other activities, such as carrying nectar and pollen. Based our observation and Inoue et al. (1985), individual of bee who carrying resin take longer handling time ( 23 minutes) and spend a longer time duration of staying in the nest. This suggested that the sticky character of resin caused a long handling time to release resin from the body.

Flight activities of bees forager could associate with choice for collecting material. Observation showed that activity of carrying resins and nectar increased when the activity of carrying pollen decreased (Figure $3 \mathrm{~b}$ ). This could be occurred due to task switching of bee foragers in collecting resources (pollen, nectar, and resin). The same individual foragers of $L$. terminata might switch from pollencollecting to resin-collecting or nectar-collecting in a day. There are several bee foragers who perform to switch become pollen-nectar foragers (Inoue et al. 1985; De Bruijn and Sommeijer 1997; Biesmeijer and Toth 1998). Inoue et al. (1985) stated the pollen forager of stingless bees can switch to collect nectar and conversely, but they do not switch to take the resin on T. minangkabau. Collecting resin is a special task in Melipona due to limited number of bee foragers (Biesmeijer and Toth 1998). However, in present study, the pollen-collecting stingless bee could switch their job position into the resin-collecting where the handling time between pollen-collecting and resincollecting are quite similar (De Bruijn and Sommeijer 1997). The choice for collecting material of stingless bee are influenced by colony needed (Biesmeijer and Toth 1998).
Flight activity of leaving the nest without carrying garbage were higher in the mid-day (12.00-13.00). Flight activities leaving the nest without carrying garbage at the same intervals were proportional with activity of returning to the nest carrying nectar and resin (Figure 3). It may be the individual bees who leaving the nest without carrying garbage was the same individuals of returning to the nest carrying nectar and resins. Leonhardt et al. (2007) reported that high activity of leaving the nest is largely take the nectar. Activity of leaving the nest with carrying garbage occurred in the morning (09.00-1000)(Figure 3a). Peak of, activity leaving the nest with carrying garbage occurred in the same intervals with activity carrying pollen. Biesmeijer and Toth (1998) also reported that activity of carrying garbage occurred in the morning where bees flew around the nest (orientation flight) without collecting any materials. In the morning, throw out activity of garbage could be performed to clean the nest from the residue of egg hatched. It may be related to the eggs place formation for increasing the productivity of the colony.

\subsection{Pollen Types and Pollen Load}

Four types of pollens were identified in this study consists of four plant families (Figure 4). The abundance and proximity of food sources will be optimized in getting pollen and nectar. Moreover, the food availability, quality, and quantity of pollen and nectar in each flower caused stingless bee choose food source preference (Heard 1999; Jongjitvimol and Wattanachaiyingcharoen 2006). The dominant pollen carried by L. terminata was pollen of Araceae (Table 3). It was suggested high availability of Araceae in this area and it was preferred by L. terminata. Amzi et al. (2015) stated that fragrance and flower shape affect bees to find food. The previous report by Pangestika (2016) showed that four pollen types carried by $L$. terminata in West Java, Indonesia. It showed that, the pollen types collected by L. terminata from October to November were not significantly different with this research. In the other hand, pollen types carried by 10 colonies of $L$. terminata in longer observation there were 38 pollen types in the Nam Nao National Park Thailand (Jongjitvimol and Poolprasert 2014) and 11 pollen types in Terengganu, Malaysia(Amzi etal.2015). It is showed that number of colonies, observation time, and landscape structure greatly influences the number of pollen types collected by the stingless bees (Ramalho et al. 1994; Priawandiputra et al. 
2015). The number of pollen types could be related to the availability and flowering period of plants as food sources. Generally, stingless bees have a preference to food source in the environment. Stingless bee species shows different food preferences (Eltz et al. 2001; Jongjitvimol and Wattanachaiyingcharoen 2006). Foraging activities of bees tend to visit flowers of the same plant species (flower constancy) (Table 3). On a single trip, bee commonly visit one species of plants. The visiting consistency of bee in collecting flower resources relates to the quality and quantity of pollen and nectar (Heard 1999).

The average of pollen load carried by individual of $L$. terminata was 32,696 pollen grains (Table 3 ). Meanwhile, other studies showed that same bee species carried less pollen grains compared to present study, i.e., 26,940 pollen grains (Asmini 2016) and 23,017 pollen grains (Pangestika 2016). The number of pollen grains carried by bees depends on the pollen type (Ramalho et al. 1994). Our results showed that $L$. terminata prefer pollen of Araceae because its small size $( \pm 10 \mu \mathrm{m})$, while other studies showed that most pollen attached in L. terminata was belonging to Euporbiaceae and Brassicaceae where the pollen sizes are more than $50 \mu \mathrm{m}$ (Asmini 2016; Pangestika 2016). However, some individuals in present study also carried large pollen, such as pollen of family Anacardiaceae and Aceraceae (Figure 4). The various shape, size, colour, and odor of flowers are an important factors for food preference of bees (Amzi et al. 2015; Jongjitvimol and Wattanachaiyingcharoen 2006). Lepidotrigona terminata can handle small size flower to collect the pollen and nectar resources. Heard (1999) stated that activities of bees to collect the pollens related to plants pollination. These results indicated that $L$. terminata is one species of stingless bees that potentially for plants pollination.

In conclusion, this study has provided flight activities information which represent the effective foraging activity to collect pollen, nectar, and resin of $L$. terminata, from the morning to mid-day. During foraging period, $L$. terminata carried four pollen types where the dominant pollen was from Araceae $(452,405$ pollen grains). The size of pollen grains is one of the main factors in attracting the L. terminata. Identification of pollen type attached on L. terminata, is provides the important information about which plants as sources of bee forage and also to be used as cultivation strategy of bees. Some environmental factors, such as temperature, light intensity, and humidity could affect the flight activities of $L$. terminata.

\section{Acknowledgements}

We are grateful to Selly, Mutiara, and Norita as a member of research group who have helped us to maintain bees colony and helping identification of the pollens.

\section{References}

[APSA] Australasia Pollen and Spore Atlas. 2007. Australian National University. Canberra. Avilable at: http:// apsa.anu.edu.au [Date accessed: 20 February 2017]

Asmini 2016. The Role of Stingless Bees (Trigona spp.: Apidae: Melliponinae) in Pollination and seed set of mustard (Brassica rapa L: Brassicaceae) [Thesis]. Indonesia, Bogor: Bogor Agricultural University.

Atmowidi T et al. 2007. Diversity of pollinator insects in relation to seed set of mustard (Brassica rapa L.: Cruciferae). HAYATI J Biosci 14:155-161.

Atmowidi T et al. 2008. Pollination effectiveness of Apis cerana Fabricus and Apis mellifera Linnaeus (hymenoptera: apidae) in Jatropha curcas L. (Euphorbiaceae). Biotropia 15:129-134.

Azmi WA et al. 2015. Melissopalynology and foraging activity of stingless bees, Lepidotrigona terminata (Hymenoptera: Apidae) from apiary in Besut, Terengganu. J Sustain Sci Manage 10:27-35.

Bhuiyan $\mathrm{KH}$ et al. 2002. Identification of bee plants and analysis of honey collected from different plant sources. Pakistan journal of Biological Sciences 5:11991201.

Biesmeijer JC, Toth E. 1998. Individual foraging, activity level and longevity in the stingless bee Melipona beecheii in Costa Rica (Hymenoptera, Apidae, Meliponinae). Insectes soc 45:427-443.

Boongird S, Michener CD. 2010. Pollen and propolis collecting by male stingless bees (Hymenoptera: Apidae). Kansas Entomological Society 83:47-50. DOI:10.2317| JKES0810.20.1

De Bruijn LLM, Sommeijer MJ. 1997. Colony foraging in different species of stingless bees (Apidae, Meliponinae) and the regulation of individual nectar foraging. Insectes soc 44:35-47.

Duangphakdee O et al. 2009. Ant repellent resins of honey bees and stingless bees. Insectes soc 56:333-339. DOI:10.1007/s00040-009-0027-z

Eltz T et al. 2001. Pollen foraging and resource partitioning of stingless bees in relation to flowering dynamics in a Southeast Asian tropical rainforest. Insectes soc 48:273-279.

Eltz T, Gorke C. 2002. Collection of mold (Rhizopus sp.) spores in lieu of pollen by the stingless bee Trigona collina. Insectes Soc 49:28-30. DOI:10.1007/s00040-0028274-2

Erdtman G. 1960. The acetolysis method. A revised description. Svensk Botanisk Tidskrift 54:561-564.

Heard TA, Hendrikz JK. 1993. Factors Influencing flight activity of colonies of the stingless bee Trigona carbonaria (Hymenoptera: Apidae). Aust J Zool 41:343-53. DOI:10.1071/Z09930343 
Heard TA. 1999. The role of stingless bees in crop pollination. Annu Rev Entomol 44:183-206.

Huang TC. 1972. Pollen Flora of Taiwan. Taiwan: National Taiwan Univ Pr.

Inoue $\mathrm{T}$ et al. 1985. Foraging behavior of workers and foraging dynamics of colonies of three Sumatran stingless bees. Res Popul Ecol 27:373-392.

Jongjitvimol T, Wattanachaiyingcharoen W. 2006. Pollen food sources of the stingless bees Trigona apicalis Smith, 1857, Trigona collina Smith, 1857 and Trigona fimbriata Smith, 1857 (Apidae, Meliponinae) in Thailand. Nat Hist J Chulalongkorn Univ 6:75-82.

Jongjitvimol T, Poolprasert P. 2014. Pollen sources of stingless bees (Hymenoptera: Meliponinae) in Nam Nao National Park, Thailand. NU International of Science $11: 1-10$.

Kelber A et al. 2006. Light intensity limits foraging activity in nocturnal and crepuscular bees. Behav Ecol 7:63-72. DOI:10.1093/beheco/arj001

Klein AM et al. 2003a. Pollination of Coffea canephora in relation to local and regional agroforestry management. J Appl Ecol 40:837-845.

Klein AM et al. 2003b. Fruit set of highland coffee increases with the diversity of pollinating bees. Proc $R$ Soc 270:955-961. DOI:10.1098/rspb.2002.2306

Krebs CJ. 1998. Ecological Methodology. Colombia: University of British.

Lehmberg L et al. 2008. Defensive behavior and chemical deterrence against ants in the stingless bee genus Trigona (Apidae, Meliponini). Journal of Apicultural Research 47:17-21. DOI:10.1080/00218839.2008.111 01418

Leonhardt SD et al. 2007. Foraging loads of stingless bees and utilisation of stored nectar for pollen harvesting. Apidologie. 38: 125-135. DOI: 10.1051/ apido:2006059.

Manly BFJ et al. 1993. Recourse Selection by Animals: Statistical Design and Analysis for Field Studies. London: Chapman and Hall.

Michener CD. 1974. The Social Behaviour of the Bees. Cambridge: The Belknap of Harvard Univ Pr.

Nagamitsu T, Inoue T. 2002. Foraging activity and pollen diets of subterranean stingless bee colonies in response to general flowering in Sarawak, Malaysia. Apidologie 33:303-314. DOI:10.1051/apido:2002016

Nugroho RB, Soesilohadi RCH. 2015. Foraging activity of worker stingless bee, Trigona sp (Hymenoptera: Apidae) in Gunungkidul. Biomedika 8:37-41. DOI:10.31001/biomedika.v8i1.193
Pangestika NW. 2016. Additional Nest Structure and Flower Constancy of Stingless Bees (Hymenoptera: Apidae) [Thesis]. Indonesia, Bogor: Bogor Agricultural University.

Priawandiputra W et al. 2015. Comparison of abundance and diversity of bees (hymenoptera: apoidea) collected by window traps among four types of forest on noto Peninsula, japan. Far East Entomol 287:1-23.

Ramalho M et al. 1994. Pollen harvest by stingless bee forager (Hymenoptera, Apidae, Meliponinae). Grana 33:239244. DOI:10.1080/00173139409429005

Ramalho $\mathrm{M}$ et al. 1998. Within-colony size variation of foragers and pollen load capacity in the stingless bee Melipona quadrifasciata anthidioides Lepeletier (Apidae: Hymenoptera). Apidologie 29:221-228.

Sakagami SF, Yamane S. 1987. Oviposition behavior and related notes of the Taiwanese stingless bee Trigona (Lepidotrigona) ventralis hoozanal. J Ethol 5:17-27.

Sakagami SF et al. 1989. Nests of the Myrmecophilous stingless bee, Trigona moorei: how do bees initiate their Nest within an arboreal ant nest?. Biotropica 21:265-274.

Smith DR. 2012. Key to Workers of Indo-Malayan stingless bees. In: Proceedings of the 11th International Conference of the Asian Apicultural Association, Kuala Terengganu, Malaysia, Vol 1. Terengganu: Kansas Univ Pr. pp. 1-42.

Sommeijer MJ et al. 1983. A comparative study of foraging behavior and pollen resources of various stingless bee (Hym., Meliponinae) and (Hym., Apinae) in Trinidad, West-Indies. Apidologie 14:205-224.

Stone GN, Willmer PG. 1989. Warm-up rates and body temperatures in bees: the importance of body size, thermal regime and phylogeny. J Exp Biol 147:303328.

Schwarz HF. 1939. The Indo-Malayan species of Trigona. Bulletin of the American Museum of Natural History. 76:83-141.

Syafrizal et al. 2014. Biodiversity and habitat of Trigona at secondary tropical rain forest of lempake ed-ucation forest, Samarinda, Kalimantan Timur.Jurnal Teknologi Pertanian 9:34-38.

Vicens N, Bosch J. 2000. Weather-dependent pollinator activity in an Apple orchard, with special reference to Osmia cornuta and Apis mellifera (Hymenoptera: Megachilidae and Apidae). Environ Entomol 29:413420. DOI:10.1603/0046-225X-29.3.413

Wille A. 1983. Biology of the stingless bees. Annu Rev Entomol 28:41-64. 